\title{
New therapeutic approaches to HGPS based on progerin inhibition
}

\author{
Camilla Pellegrini \\ From 1st French-Italian meeting on laminopathies and other nuclear envelope-related diseases \\ Marseille, France. 15-16 January 2015
}

Hutchinson-Gilford Progeria Syndrome (HGPS) is caused by a de novo heterozygous mutation on LMNA gene that leads to accumulation of progerin, a mutant form of prelamin A. HGPS skin fibroblasts are characterized by multiple nuclear defects: nuclear shape abnormalities chromatin structure alterations, increased DNA damage and cell cycle alterations.

Retinoic acid may modulate LMNA gene transcription, due to the presence of a retinoic acid responsive element (L-RARE) in the LMNA promoter. Based on this knowledge, we investigated if all trans retinoic acid (ATRA) could lower progerin levels in HGPS fibroblasts. We also evaluated the effects of a combined treatment with rapamycin, a drug known to promote autophagy and reduce both farnesylated prelamin A and progerin amount.

We demonstrate a surprising effect of ATRA to repress Lamin A/C gene transcription and we show that the combined treatment with ATRA and rapamycin has a synergistic effect: it dramatically lowers progerin levels, restores both heterochromatin organization and nuclear shape, reduces DNA damage markers and improves cell viability. These promising results could open the way to a new therapeutic approach for HGPS.

Published: 11 November 2015

doi:10.1186/1750-1172-10-S2-O8

Cite this article as: Pellegrini: New therapeutic approaches to HGPS

based on progerin inhibition. Orphanet Journal of Rare Diseases 201510

(Suppl 2):08.

Correspondence: camilla.pellegrini@ior.it

CNR Institute for Molecular Genetics, Unit of Bologna, Bologna, Italy, Rizzoli Orthopedic Institute, Laboratory of Musculoskeletal Cell Biology, Bologna, Italy

Submit your next manuscript to BioMed Central and take full advantage of:

- Convenient online submission

- Thorough peer review

- No space constraints or color figure charges

- Immediate publication on acceptance

- Inclusion in PubMed, CAS, Scopus and Google Scholar

- Research which is freely available for redistribution 